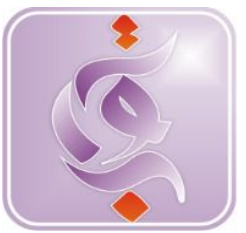

\title{
KONSTRUKSI ALAT UKUR CONSUMER SATISFACTION PADA MASYARAKAT PENGGUNA LAYANAN KELURAHAN
}

Received: 02 ${ }^{\text {th }}$ September 2019; Revised: 04 $4^{\text {th }}$ October 2019; Accepted: $18^{\text {th }}$ October 2019

\section{Nurul Arbiyah}

Fakultas Psikologi, Universitas Indonesia

Email: nurul.arbiyah31@ui.ac.id

\section{Dyah Putri Pertiwi}

Fakultas Psikologi, Universitas Indonesia

\section{Laksmita Aulia Dewi}

Fakultas Psikologi, Universitas Indonesia Nadia Anindita Vandari

Fakultas Psikologi, Universitas Indonesia

\begin{abstract}
Abstrak. Penelitian ini bertujuan untuk mengembangkan alat ukur kepuasan konsumen (consumer satisfaction) pada masyarakat pengguna layanan kelurahan, yaitu alat ukur Kepuasan Pelayanan Kelurahan (KPK). Alat ukur ini dibuat karena dirasa belum ada alat ukur yang memadai untuk mengukur kepuasan konsumen kelurahan di Indonesia. Dasar teori yang digunakan dalam penelitian ini adalah teori Expectation Disconfirmation Paradigm (EDP) dari Oliver. Populasi pengguna alat ukur KPK adalah masyarakat yang mendapatkan layanan kelurahan dalam satu bulan terakhir. Pengujian alat ukur dilakukan pada 58 responden ( 1 penilai ahli dan 12 responden untuk pengujian kualitatif, 45 responden untuk pengujian kuantitatif) yang dipilih menggunakan teknik accidental sampling. Data dikumpulkan menggunakan kuesioner dan dianalisis secara kuantitatif dan kualitatif. Uji reliabilitas menghasilkan $\mathrm{a}=0.974$, yang menunjukkan item-item KPK konsisten dalam mengukur konstruk tertentu. Pengujian validitas konstruk dengan metode correlation with other test menghasilkan koefisien korelasi dengan alat ukur SERVQUAL sebesar $\mathrm{r}=0.383, \quad \mathrm{p}<0.01$, one-tailed, yang menunjukkan KPK valid dalam mengukur konstruk kepuasan konsumen. Analisis item secara kuantitatif dilakukan dengan mempertimbangkan nilai proportion of endorsement dan corrected item-total correlation. Item yang dipilih ialah 30 item terbaik dari 57 item yang dibuat. Norma dibentuk dengan menggunakan metode scaled score.
\end{abstract}

Kata kunci: Kepuasan Konsumen; Kelurahan; Reliabilitas; Validitas.

\section{PENDAHULUAN}

Keluhan masyarakat terkait dengan pelayanan publik belakangan ini masih cukup sering terlihat di kanal-kanal pengaduan layanan publik. Salah satu instansi yang cukup banyak menerima keluhan terkait pelayanannya adalah pemerintah daerah. Menurut data statistik yang dimiliki Ombudsman Republik Indonesia, sebanyak 2.853 dari 6.859 laporan pengaduan masyarakat yang masuk pada tahun 2015 merupakan pengaduan mengenai kondisi pelayanan publik di instansi pemerintahan daerah atas dugaan maladministrasi (Ombudsman, 2015). Amzulian Rifai, ketua Ombudsman RI, menambahkan bahwa keluhan yang paling banyak didapatkan dari masyarakat ialah pelayanan pemerintah daerah yang dianggap belum memuaskan (Masnurdiansyah, 2016).

Dalam memberikan pelayanan, hal yang perlu diperhatikan adalah kepuasan 
konsumen terhadap pelayanan yang diberikan (Adhitya, 2014). Kepuasan konsumen menurut Oliver (2015) merupakan hasil penilaian konsumen terhadap seberapa mampu suatu produk, layanan atau fitur layanan dan produk dapat memberikan perasaan terpenuhi pada konsumen (Oliver, 2015). Oliver juga menjelaskan bahwa kepuasan bersifat short-term attitude yang dapat berubah sesuai dengan lingkungan individu dan umumnya memiliki batasan, baik batas minimum (kepuasan tidak/kurang terpenuhi) maupun batas maksimum (kepuasan terpenuhi secara berlebih).

Kepuasan masyarakat terhadap pelayanan pemerintahan penting untuk dimiliki karena kepuasan tersebut dapat berpengaruh terhadap pelaksanaan programprogram pemerintah. Anggota Komisi II DPR, Ace Hasan Syadzily mengungkapkan bahwa saat ini terjadi penurunan antusiasme masyarakat dalam mengurus e-KTP (Pratama, 2017). Ace menyatakan jika masih banyak masyarakat yang belum memiliki e-KTP, maka akan berdampak pada penyelenggaraan Pilkada tahun 2018, yang mensyaratkan pemilih untuk memiliki e-KTP (Pratama, 2017). Berdasarkan hal tersebut, terlihat bahwa pemerintah juga akan merasakan dampak yang kurang baik dari rasa tidak puas masyarakat terhadap pelayanan pemerintahan, sehingga penting untuk mengetahui kepuasan masyarakat agar pelaksanaan program pemerintahan dapat berjalan dengan lebih baik lagi.

Terdapat beberapa alat ukur terkait kepuasan konsumen yang cukup banyak dirujuk oleh berbagai negara, salah satunya adalah NCSI (National Customer Satisfaction Index). Meskipun telah banyak dirujuk, NCSI dirasa kurang cocok digunakan dalam setting pemerintahan karena turut mengukur customer loyalty atau kesetiaan pelanggan (CS Management Center, 2011). Komponen ini menjadi kurang tepat untuk digunakan oleh institusi pemerintah karena pemerintah merupakan penyedia layanan tunggal sehingga kesetiaan konsumen bersifat absolut. Indonesia sendiri melakukan pengukuran terhadap kepuasan masyarakat dengan menggunakan Indeks Kepuasan Masyarakat (IKM), namun IKM dirasa masih memiliki kekurangan dalam mengukur kepuasan konsumen. IKM dalam Kepmenpan No. 25 Tahun 2004 berbentuk kisi-kisi alat ukur, sehingga tidak praktis digunakan masingmasing pihak harus menyusun sendiri IKM mereka sebelum menggunakannya. Koefisien reliabilitas dan validitasnya pun kemungkinan akan berbeda pada tiap institusi yg menyusunnya. Selain itu, Kepmenpan No. 25 tahun 2004 juga tidak mencantumkan teori yang jelas sebagai acuan dalam menyusun indikator alat ukur ini sehingga tidak bisa diketahui apakah alat ukur ini mengukur kepuasan pelanggan dengan benar.

Berdasarkan penjelasan di atas, pengembangan alat ukur baru yang sesuai dengan kondisi di Indonesia dan benar-benar menggambarkan kepuasan konsumen terhadap pelayanan publik di instansi pemerintahan daerah perlu dikembangkan, khususnya pada instansi pemerintah daerah tingkat kelurahan. Hal ini didasari oleh pemikiran bahwa kelurahan merupakan instansi pemerintah daerah pertama yang dekat secara langsung dengan masyarakat (Utomo, 2008). Alat ukur ini diharapkan memiliki item mengukur konstruk yang diukur secara konsisten, valid dalam mengukur kepuasan masyarakat terhadap pelayanan pemerintah daerah (dalam hal ini yaitu kelurahan) sesuai dengan pembandingnya yaitu kualitas layanan, memiliki item-item yang dapat membedakan masyarakat dengan tingkat kepuasan yang berbeda, serta memiliki norma yang tepat. 
93 Jurnal Al-Qalb, Jilid 10, Nomor 2, Oktober 2019, hlm. 91-102

\section{METODE}

\section{Partisipan}

Populasi dalam penelitian ini adalah masyarakat pengguna layanan kelurahan. Sampel penelitian ini adalah masyarakat pengguna layanan kelurahan dengan kriteria yaitu telah menggunakan layanan kelurahan dalam waktu satu bulan terakhir. Total partisipan yang didapatkan adalah 58 orang, yaitu 1 orang penilai ahli, 12 orang partisipan pengujian kualitatif, dan 45 partisipan pengujian kuantitatif. Partisipan uji kualitatif didapatkan dengan menjaring orang-orang di sekitar peneliti yang pernah mengunjungi dan menggunakan layanan kelurahan dalam 1 bulan terakhir. Pada pengujian kuantitatif, tim peneliti mengunjungi beberapa kantor kelurahan di wilayah Depok dan Tangerang Selatan untuk mengambil data secara langsung dari para pengunjung kantor kelurahan.

\section{Pengukuran}

Penyusunan alat ukur consumer satisfaction ini menggunakan dimensi layanan. Kualitas layanan ini dapat diketahui dari seberapa baik performa dari atributatribut layanan dari perspektif konsumen dengan asumsi bahwa terdapat kesepakatan umum mengenai makna dari performa (Oliver, 2015). Meskipun kualitas layanan dan consumer satisfaction merupakan dua konstruk yang berbeda, Oliver (2015) menyatakan bahwa hal ini memungkinkan untuk dilakukan karena atribut layanan yang sama dapat digunakan untuk mengukur kedua hal tersebut. Yang membedakan adalah pada pengukuran kualitas layanan ekspektasi yang digunakan merupakan ideal expectation sedangkan pada kepuasan konsumen yang digunakan merupakan predictive expectation. Ideal expectation adalah bagaimana idealnya kualitas suatu layanan yang akan dikonsumsi menurut konsumen, sedangkan predictive expectation merupakan prediksi atau perkiraan konsumen terhadap seberapa baik kualitas dari layanan yang akan dikonsumsinya. Dalam penyusunannya, individu diminta untuk membandingkan apa yang ia harapkan dan apa yang dia dapatkan di kelurahan.

Menurut Parasuraman, Zeithaml dan Barry (1985), terdapat lima dimensi layanan yaitu tangible, reliability, responsiveness, assurance, dan emphaty. Tangible dijelaskan sebagai bukti fisik dari pelayanan. Reliabilty ialah kemampuan untuk berperforma melayani dengan cara yang dapat diandalkan dan secara akurat. Responsisveness ialah kemauan atau kesiapan petugas untuk memberikan pelayanan. Dimensi assurance berkaitan dengan pengetahuan dan kesopanan dari petugas (atau karyawan) dan kemampuan mereka dalam membangkitkan rasa percaya (trust) serta kepercayaan diri (confidence). Terakhir, empathy yaitu rasa peduli, perhatian individual yang disediakan oleh perusahaan bagi konsumen.Berikut ini adalah tabel kisi-kisi alat ukur Kepuasan Pelayanan Kelurahan (KPK). 
94 Jurnal Al-Qalb, Jilid 10, Nomor 2, Oktober 2019, hlm. 91-102

Tabel 1

Tabel kisi-kisi alat ukur Kepuasan Pelayanan Kelurahan (KPK)

\begin{tabular}{|c|c|c|c|c|c|}
\hline Konstruk & Atribut & $\begin{array}{l}\text { Target } \\
\text { item }\end{array}$ & $\begin{array}{c}\text { Jumlah } \\
\text { item } \\
\text { yang } \\
\text { dibuat }\end{array}$ & Indikator & Contoh item \\
\hline \multirow{7}{*}{$\begin{array}{l}\text { Kepuasan } \\
\text { konsumen } \\
\text { merupakan } \\
\text { Penilaian } \\
\text { konsumen } \\
\text { terhadap } \\
\text { fitur dari } \\
\text { suatu } \\
\text { produk/laya } \\
\text { nan atau } \\
\text { penilaian } \\
\text { atas } \\
\text { produk/laya } \\
\text { nan itu } \\
\text { sendiri } \\
\text { (Oliver, } \\
\text { 2015) }\end{array}$} & \multirow{3}{*}{$\begin{array}{l}\text { tangible: } \\
\text { bukti fisik } \\
\text { dari } \\
\text { pelayanan }\end{array}$} & \multirow{3}{*}{6} & \multirow{3}{*}{12} & $\begin{array}{l}\text { Fasilitas yang } \\
\text { tersedia }\end{array}$ & Kenyamanan kursi di ruang tunggu \\
\hline & & & & $\begin{array}{l}\text { Peralatan untuk } \\
\text { menunjang } \\
\text { pelayanan yang } \\
\text { tersedia }\end{array}$ & $\begin{array}{l}\text { Ketersediaan komputer untuk } \\
\text { menunjang pelayanan. }\end{array}$ \\
\hline & & & & $\begin{array}{l}\text { Representasi fisik } \\
\text { dari pelayanan } \\
\text { (seperti: kartu, kertas } \\
\text { akte, dan Kartu } \\
\text { Keluarga) }\end{array}$ & $\begin{array}{l}\text { Ketersediaan dokumen kelengkapan } \\
\text { layanan (misal: formulir, blangko, } \\
\text { materai) }\end{array}$ \\
\hline & \multirow{2}{*}{$\begin{array}{l}\text { reliability: } \\
\text { kemampuan } \\
\text { untuk } \\
\text { berperforma } \\
\text { melayani } \\
\text { dengan cara } \\
\text { yang dapat } \\
\text { diandalkan } \\
\text { dan secara } \\
\text { akurat }\end{array}$} & \multirow[b]{2}{*}{6} & \multirow[b]{2}{*}{12} & $\begin{array}{l}\text { Ketepatan dalam } \\
\text { pelayanan }\end{array}$ & $\begin{array}{l}\text { Ketepatan penulisan nama saya (atau } \\
\text { keluarga) dalam dokumen yang dibuat }\end{array}$ \\
\hline & & & & $\begin{array}{l}\text { Kesesuaian } \\
\text { pelayanan dalam } \\
\text { rentang waktu yang } \\
\text { ditentukan }\end{array}$ & $\begin{array}{l}\text { Kesesuaian waktu penyelesaian } \\
\text { dokumen dengan waktu yang } \\
\text { ditentukan atau dijanjikan oleh petugas }\end{array}$ \\
\hline & \multirow{2}{*}{$\begin{array}{l}\text { responsivene } \\
\text { ss: kemauan } \\
\text { atau kesiapan } \\
\text { petugas untuk } \\
\text { memberikan } \\
\text { pelayanan }\end{array}$} & \multirow[t]{2}{*}{6} & \multirow[t]{2}{*}{8} & $\begin{array}{l}\text { Ketanggapan petugas } \\
\text { dalam membantu } \\
\text { konsumen yang } \\
\text { membutuhkan } \\
\text { pelayanan. }\end{array}$ & $\begin{array}{l}\text { Ketanggapan petugas dalam } \\
\text { memberikan pelayanan kepada saya }\end{array}$ \\
\hline & & & & $\begin{array}{l}\text { Pemberian pelayanan } \\
\text { oleh petugas dengan } \\
\text { cepat }\end{array}$ & $\begin{array}{l}\text { Kecepatan pemeriksaan berkas oleh } \\
\text { petugas }\end{array}$ \\
\hline
\end{tabular}


95 Jurnal Al-Qalb, Jilid 10, Nomor 2, Oktober 2019, hlm. 91-102

\begin{tabular}{|c|c|c|c|c|}
\hline \multirow{3}{*}{$\begin{array}{l}\text { assurance : } \\
\text { pengetahuan } \\
\text { dan } \\
\text { kesopanan } \\
\text { dari petugas } \\
\text { (atau } \\
\text { karyawan) } \\
\text { dan } \\
\text { kemampuan } \\
\text { mereka dalam } \\
\text { membangkitk } \\
\text { an rasa } \\
\text { percaya } \\
(\text { trust) }\end{array}$} & \multirow{3}{*}{6} & \multirow[t]{3}{*}{12} & $\begin{array}{l}\text { Pengetahuan dan } \\
\text { keterampilan } \\
\text { interpersonal yang } \\
\text { dimiliki oleh petugas. }\end{array}$ & $\begin{array}{l}\text { Kemampuan berkomunikasi petugas } \\
\text { pelayanan. }\end{array}$ \\
\hline & & & $\begin{array}{l}\text { Pengetahuan dan } \\
\text { keterampilan teknis } \\
\text { yang dimiliki oleh } \\
\text { petugas.. }\end{array}$ & $\begin{array}{l}\text { Pemahaman petugas terhadap } \\
\text { layanan-layanan yang tersedia di } \\
\text { kelurahan }\end{array}$ \\
\hline & & & $\begin{array}{l}\text { Kebersihan dan } \\
\text { kerapihan petugas. }\end{array}$ & $\begin{array}{l}\text { Kerapihan berpakaian dari petugas } \\
\text { pelayanan kelurahan }\end{array}$ \\
\hline \multirow{4}{*}{$\begin{array}{l}\text { empathy : } \\
\text { rasa peduli } \\
\text { dan perhatian } \\
\text { individual } \\
\text { yang } \\
\text { disediakan } \\
\text { oleh } \\
\text { perusahaan } \\
\text { bagi } \\
\text { pelanggan }\end{array}$} & \multirow[b]{3}{*}{6} & \multirow{4}{*}{12} & $\begin{array}{l}\text { Kesesuaian } \\
\text { pelayanan dengan } \\
\text { jam operasional. }\end{array}$ & $\begin{array}{l}\text { Kesesuaian jam buka kelurahan dengan } \\
\text { jam kerja }\end{array}$ \\
\hline & & & $\begin{array}{l}\text { Penjelasan oleh } \\
\text { petugas mengenai } \\
\text { pelayanan yang ada }\end{array}$ & $\begin{array}{l}\text { Pemberian informasi mengenai layanan } \\
\text { kelurahan dari petugas pelayanan }\end{array}$ \\
\hline & & & \begin{tabular}{|l} 
Kemampuan \\
meyakinkan \\
konsumen bahwa \\
masalah akan \\
ditangani
\end{tabular} & $\begin{array}{l}\text { Kemampuan petugas dalam } \\
\text { menyelesaikan masalah pelayanan } \\
\text { yang saya alami. }\end{array}$ \\
\hline & & & $\begin{array}{l}\text { Atensi atau fokus } \\
\text { dari petugas ketika } \\
\text { memberikan } \\
\text { pelayanan. }\end{array}$ & $\begin{array}{l}\text { Perhatian petugas ketika memberikan } \\
\text { pelayanan kepada saya }\end{array}$ \\
\hline
\end{tabular}

Dalam pengujian psikometrik, Alat ukur yang digunakan untuk melakukan uji validitas adalah SERVQUAL yang merupakan alat ukur yang mengukur persepsi kualitas pelayanan (service quality) dengan pertimbangan bahwa kepuasan masyarakat memiliki korelasi positif dengan kualitas pelayanan (Sureshchandar, Rajendran, \&
Anantharaman, 2002) Alat ukur SERVQUAL memiliki internal consistency sebesar 0,9545 (Adhitya, 2014). Alat ukur SERVQUAL juga telah terbukti valid, dengan koefisien validitas sebesar 0,3601 (Adhitya, 2014). 
96 Jurnal Al-Qalb, Jilid 10, Nomor 2, Oktober 2019, hlm. 91-102

\section{Prosedur}

Penyusunan alat ukur dilakukan dengan konseptualisasi tes, konstruksi tes, uji coba alat ukur, analisis, revisi. Peneliti melakukan pengujian kualitatif dengan cara uji coba keterbacaan alat ukur. Analisis dilakukan secara kuantitatif dan kualitatif dengan cara menentukan dan melakukan teknik pengujian reliabilitas, validitas, melakukan analisis item. Setelah melakukan pengujian, peneliti melakukan revisi, uji psikometrik akhir, dan pembuatan norma.

\section{Konseptualisasi tes}

Berdasarkan jenis tingkah laku yang diukur, administrasi alat ukur Kepuasan Pelayanan Kelurahan (KPK) termasuk tipe tes kepribadian, yang mana alat ukur ini mengukur konstruk berdasarkan pikiran, perasaan, dan tingkah laku yang biasa dilakukan oleh partisipan. Ciri-ciri tes ini adalah tidak terdapat jawaban yang benar atau salah. Berdasarkan cara pengadministrasian, alat ukur ini menggunakan format paper and pencil. Lalu berdasarkan prosedur administrasinya, tes ini diadministrasikan secara individual (Cohen et al., 2013).

Pada tahap pemilihan bentuk item, peneliti menggunakan frasa yang merupakan komponen dari pelayanan kelurahan. Untuk setiap item, peneliti menggunakan skala Likert dari 1 ("Jauh lebih buruk dari yang saya perkirakan") hingga 7 ("Jauh lebih baik dari yang saya perkirakan"). Bentuk item ini menyesuaikan dengan cara pengukuran consumer satisfaction yang dikemukakan oleh Oliver (2010) yaitu better than/worse than scale. Item dengan bentuk better than/worse than scale mengukur kepuasan konsumen secara langsung dengan meminta konsumen membandingkan secara langsung antara realita dengan perkiraan mereka (Oliver, 2010). Penggunaan skala ini juga didasarkan pada pendapat Isac dan Rusu
(2014) yang menyatakan bahwa skala ini dapat mengukur secara langsung apa yang ingin diketahui.

\section{Konstruksi tes}

Pada tahapan ini, peneliti melakukan operasionalisasi konstruk, atribut, dan penyusunan item. Consumer satisfaction dioperasionalisasikan sebagai penilaian konsumen terhadap fitur dari suatu produk/layanan atau penilaian atas produk/layanan itu sendiri (Oliver, 2015). Consumer satisfaction dalam alat ukur ini terdiri dari lima atribut yaitu tangible, reliability, responsiveness, assurance, dan empathy. Peneliti menyusun item-item berdasarkan kelima atribut tersebut dan dilanjutkan dengan penentuan skoring dan penyusunan instruksi tes. Teknik skoring alat ukur ini menggunakan skala 1 sampai 7, dimana skala 1 berarti "jauh lebih buruk dari yang saya perkirakan", skala 2 berarti "lebih buruk dari yang saya perkirakan”, skala 3 berarti "agak lebih buruk dari yang saya perkirakan", skala 4 berarti "sama dengan yang saya perkirakan", skala 5 berarti "agak lebih baik dari yang saya perkirakan", skala 6 berarti "lebih baik dari yang saya perkirakan", dan skala 7 berarti "jauh lebih baik dari yang saya perkirakan”. Tidak ada unfavorable item dalam alat ukur ini. Berdasarkan hasil penyusunan itemnya, terdapat 57 item, dengan rentang skor 57 sampai 342. Selanjutnya, peneliti melakukan uji keterbacaan dan psikometrik.

\section{Uji Coba Alat Ukur}

Uji coba dilakukan sebanyak dua kali, yaitu uji keterbacaan dan uji psikometrik. Peneliti melakukan uji keterbacaan pada 1 orang expert judge dan 12 orang pengguna layanan kelurahan di beberapa tempat pada lokasi yang telah disepakati (di sekitar Tangerang Selatan dan Depok). Selanjutnya peneliti melakukan pengambilan data pada 
45 orang pengguna layanan kelurahan dengan menggunakan teknik sampling convenience sampling/accidental sampling. Data tersebut digunakan untuk pengujian psikometrik. Pengujian psikometrik awal terdiri dari uji reliabilitas, validitas dan analisis item. Selanjutnya pengujian psikometrik akhir terdiri dari pengujian reliabilitas, validitas, dan pembuatan norma. Peneliti melakukan pengujian reliabilitas dengan menggunakan teknik pengujian interitem consistency. Uji validitas dilakukan dengan tiga tahapan yaitu uji face validity. validitas konten, dan validitas konstruk dengan metode correlation with other test. Metode correlation with other test dilakukan dengan mengkorelasikan alat ukur yang diuji dengan alat ukur yang konstruk pada area tingkah laku yang sama, yaitu SERVQUAL.

\section{Analisis Item}

Peneliti melakukan analisis item dengan cara kualitatif dan kuantitatif. Analisis kualitatif dilakukan dengan melihat konten item dan mengevaluasi apakah penulisan item telah dilakukan secara efektif. Item pada alat ukur ini telah dilakukan analisis secara kualitatif oleh expert judgement, yakni salah satu dosen Psikologi UI. Setelah itu, peneliti melakukan uji keterbacaan kepada 12 orang masyarakat pengguna layanan kelurahan. Item yang dianggap masih belum baik kemudian dievaluasi lalu direvisi. Selanjutnya, analisis kuantitatif dilakukan dengan pengukuran item endorsement index dan corrected item-total correlation (crit). Patokan nilai PoE yang digunakan dalam penelitian ini dibagi menjadi 3 bagian, yaitu : (1) PoE $<0,15$ menandakan item cenderung dijawab tidak setuju oleh sebagian besar partisipan, mengindikasikan social desirability yang tinggi, (2) nilai PoE 0,150,85 menandakan Item memiliki distribusi jawaban merata antara yang setuju dan tidak setuju, dan nilai PoE $>0,85$ menandakan item cenderung dijawab setuju oleh sebagian besar partisipan, mengindikasikan social desirability yang rendah (Millon \& Bloom, 2008). Nilai crit yang dianggap baik apabila memiliki nilai $\geqq 0,30$ (Nunnally \& Bernstein, 1994).

\section{Revisi}

Berdasarkan jumlah item yang dibuat sebanyak 57 item, dipilih 30 item yang dianggap baik. Item-item tersebut dipilih berdasarkan hasil analisis item secara kualitatif dan kuantitaif. Terakhir, peneliti menyusun norma untuk alat ukur dengan menggunakan metode within group norm.

\section{HASIL DAN PEMBAHASAN Uji Reliabilitas Awal}

Hasil uji reliabilitas menggunakan Cronbach's Alpha menghasilkan skor $\mathrm{a}=.985$. Skor ini menunjukkan bahwa 98,5\% dari varians observed score merupakan varians true score dan 1,5\% merupakan varians error berupa content sampling error dan content heterogenity error. Dengan demikian, KPK dapat dikatakan memiliki reliabilitas yang baik karena memiliki koefisien reliabilitas yang berada di antara 0.8-0.9 (Anastasi \& Urbina, 1997).

\section{Uji Validitas Awal}

Sebelum melakukan uji validitas, peneliti melakukan uji normalitas data baik pada data KPK maupun SERVQUAL. Data dari KPK menunjukkan skor $\mathrm{D}(45)=0,987$, $\mathrm{p}>0.05, \quad$ sedangkan $\quad$ SERVQUAL menunjukkan skor $\mathrm{D}(45)=0,828, \mathrm{p}<0.01$. Hasil tersebut menunjukkan bahwa data dari KPK memiliki distribusi normal sedangkan data dari SERQUAL tidak terdistribusi normal sehingga uji validitas konstruk dilakukan menggunakan metode korelasi Spearman. Dari hasil uji validitas konstruk, didapatkan hasil koefisien korelasi sebesar 
98 Jurnal Al-Qalb, Jilid 10, Nomor 2, Oktober 2019, hlm. 91-102

$0.338(\mathrm{p}<0.05$, one tailed $)$. Hasil ini menunjukkan bahwa KPK valid dalam mengukur consumer saitsfaction serta memiliki shared variance dengan SERVQUAL sebesar 11,4\% .

\section{Analisis Item}

Analisis item dilakukan dengan melakukan perhitungan Proportion of Endorsement (PoE) dan corrected item-total correlation (crit). Berikut ini merupakan hasil perhitungan PoE.

Tabel 2

Hasil Perhitungan Proportion of Endorsement

\begin{tabular}{|c|c|c|c|c|}
\hline $\begin{array}{l}\text { PoE (Millon \& } \\
\text { Bloom, 2008) }\end{array}$ & Keterangan & Nomor item & Jumlah & Persentase \\
\hline$<0.15$ & $\begin{array}{l}\text { Item cenderung dijawab } \\
\text { tidak setuju oleh sebagian } \\
\text { besar partisipan, } \\
\text { mengindikasikan social } \\
\text { desirability yang tinggi }\end{array}$ & - & - & - \\
\hline $0.15-0.85$ & $\begin{array}{l}\text { Item memiliki distribusi } \\
\text { jawaban merata antara yang } \\
\text { setuju dan tidak setuju }\end{array}$ & $\begin{array}{l}2,3,4,6,9,10,11, \\
12,13,15,16,17, \\
20,21,22,23,24, \\
25,26,27,30,31 \\
32,37,38,47,48, \\
49,56\end{array}$ & 30 & $53 \%$ \\
\hline$>0.85$ & $\begin{array}{l}\text { Item cenderung dijawab } \\
\text { setuju oleh sebagian besar } \\
\text { partisipan, mengindikasikan } \\
\text { social desirability yang } \\
\text { rendah }\end{array}$ & $\begin{array}{l}1,5,7,8,14,18,19, \\
28,29,33,34,35, \\
36,39,40,41,42, \\
43,44,45,46,50, \\
51,52,53,54,55, \\
57\end{array}$ & 27 & $47 \%$ \\
\hline \multicolumn{3}{|c|}{ Total } & 57 & $100 \%$ \\
\hline
\end{tabular}

Selain PoE, penghitungan crit juga dilakukan untuk untuk melihat kemampuan diskriminasi item. Berikut ini adalah hasil dari penghitungan crit yang telah dilakukan pada proses pengujian alat ukur. 
Tabel 3

Hasil Perhitungan Corrected item-total correlation

\begin{tabular}{|c|c|c|c|c|}
\hline $\begin{array}{l}\text { Crit } \\
\text { (Nunnally \& } \\
\text { Bernstein 1994) }\end{array}$ & Keterangan & Nomor item & Jumlah & Persentase \\
\hline$<0,3$ & $\begin{array}{l}\text { Item tidak dapat } \\
\text { mendiskriminasi } \\
\text { dengan baik }\end{array}$ & - & - & - \\
\hline$\geq 0,3$ & $\begin{array}{l}\text { Item dapat } \\
\text { mendiskriminasi } \\
\text { dengan baik }\end{array}$ & $\begin{array}{l}1,2,3,4,5,6,7,8,9,10,11, \\
12,13,14,15,16.17,18,19, \\
20,21,22,23,24,25,26,27, \\
28,29,30,31,32,33,34,35, \\
36,37,38,39,40,41,42,43, \\
44,45,46,47,48,49,50,51, \\
52,53,54,55,56,57\end{array}$ & 57 & $100 \%$ \\
\hline \multicolumn{3}{|c|}{ Total } & 57 & $100 \%$ \\
\hline
\end{tabular}

\section{Analisis Item Terintegrasi}

Dari hasil pengujian reliabilitas dan validitas awal, selanjutnya dilakukan analisis item integratif untuk memilih 30 item terbaik dari 57 item yang ada. Pemilihan item-item tersebut didasarkan atas beberapa pertimbangan yaitu analisis kualitatif (kesesuaian item dengan indikator), kuantitatif (PoE dan crit), dan target item yang diinginkan. Selanjutnya 30 item terpilih ini kemudian diuji kembali reliabilitas dan validitasnya.

\section{Uji Reliabilitas Akhir}

Uji reliabilitas menggunakan Cronbach's Alpha menunjukkan skor 0.974, turun dari uji reliabilitas awal sebesar 0.985 , namun masih menunjukkan reliabilitas yang baik dalam mengukur suatu konstruk.
Uji validitas kedua juga menunjukkan perubahan dibandingkan dengan uji validitas sebelumnya. Pengujian menggunakan korelasi Spearman menghasilkan koefisien korelasi sebesar $0.383(\mathrm{p}<0.01$, one-tailed $)$, meningkat dari hasil uji validitas sebelumnya. Hasil ini menunjukkan bahwa KPK valid dalam mengukur consumer satisfaction dan memiliki shared variance dengan SERVQUAL sebesar $14.6 \%$.

\section{Norma}

Pembuatan norma alat ukur Kepuasan Konsumen Kelurahan (KPK) menggunakan norma kelompok yaitu within-group norm dengan scaled score. Norma dibuat dengan melakukan transformasi linear karena data yang didapatkan memiliki distribusi normal. Berikut adalah tabel norma untuk KPK.

\section{Uji Validitas Akhir}


100 Jurnal Al-Qalb, Jilid 10, Nomor 2, Oktober 2019, hlm. 91-102

Tabel 4

Tabel Norma Alat Ukur Kepuasan Pelayanan Kelurahan

\begin{tabular}{|c|c|}
\hline SCALED SCORE (SS) & RAW SCORE (RS) \\
\hline 16 & $204-210$ \\
\hline 15 & $194-203$ \\
\hline 14 & $183-193$ \\
\hline 13 & $173-182$ \\
\hline 12 & $163-172$ \\
\hline 11 & $152-162$ \\
\hline 10 & $142-151$ \\
\hline 9 & $132-141$ \\
\hline 8 & $121-131$ \\
\hline 7 & $111-120$ \\
\hline 6 & $100-110$ \\
\hline 5 & $90-99$ \\
\hline 4 & $80-89$ \\
\hline 3 & $70-79$ \\
\hline 2 & $60-69$ \\
\hline 1 & $<60$ \\
\hline & \\
\hline
\end{tabular}

\section{KESIMPULAN}

Berdasarkan pengujian kembali setelah pemilihan item, didapatkan hasil uji reliabiltas, validitas akhir, dan pembuatan norma. Dari hasil pengujian, alat ukur ini dianggap reliabel, yang berarti item-item dalam alat ukur konsisten mengukur konstruk tertentu. Selain itu, dilakukan pula mengujian validitas konstruk dengan mengorelasikan alat ukur Kepuasan Pelayanan Konsumen (KPK) dengan alat ukur SERVQUAL. Hasil pengujian menunjukkan bahwa alat ukur KPK memiliki korelasi yang signifikan dengan alat ukur SERVQUAL. Dengan kata lain alat ukur ini valid dalam mengukur konstruk kepuasan konsumen pengguna layanan kelurahan, yang berarti bahwa alat ukur ini memang benar-benar mengukur apa yang ingin diukur. Dari 57 item awal yang telah disusun, dipilih 30 item terbaik sebagai hasil akhir dari alat ukur. Dari penghitungan proportion of endorsement, didapatkan hasil bahwa sebagian besar item memiliki distribusi jawaban merata antara yang setuju dan tidak setuju. Item-item juga ini dianggap cukup baik dan dapat membedakan masyarakat yang memiliki kepuasan konsumen yang tinggi dan masyarakat yang memiliki kepuasan konsumen yang rendah. Terakhir, norma dibuat menggunakan scaled score $(\mathrm{M}=10, \mathrm{SD}=3)$ yang memungkinkan untuk melakukan perbandingan skor individu dengan kelompok standar yang berasal dari populasi yang sama, yaitu masyarakat pengguna layanan kelurahan.

\section{DAFTAR PUSTAKA}

Adhitya, T.J. (2014). Analisis kepuasan masyarakat atas kualitas pelayanan di 
101 Jurnal Al-Qalb, Jilid 10, Nomor 2, Oktober 2019, hlm. 91-102

kantor kelurahan Pejaten Barat kecamatan Pasar Minggu Jakarta Selatan. Depok: Univeristas Indonesia.

Anastasi, A. \& Urbina, S. (1997). Psychological Testing 7th ed. Upper Saddle River, NJ: Prentice Hall.

Bouckaert, G., \& Van de Walle, S. (2003). Comparing measures of citizen trust and user satisfaction as indicators of 'good governance': Difficulties in linking trust and satisfaction indicators. International Review of Administrative Sciences, 69(3), 329-343.

Churchill Jr, G. A., \& Surprenant, C. (1982). An investigation into the determinants of customer satisfaction. Journal of Marketing Research, 491-504.

Cohen, R., Swerdlik, M. \& Sturman E. (2013). Psychological Testing and Assessment: An Introduction to Test and Measurement 8th ed. New York, NY: McGraw-Hill.

Cronbach, L.J.. \& Meehl, P. E. (1955). Construct validity in psychological test. Psychological Bulletin, 52: 281302

CS Management Center. (2011). Introduction to the NCSI. Diakses pada 16 September $\quad 2017$ dari http://www.ncsi.or.kr/ncsi/ncsi.list.asp? $\underline{\text { menuseqnum }=8 \& \text { siteid }=1}$

Fornell, C., Johnson, M. D., Anderson, E. W., Cha, J., \& Bryant, B. E. (1996). The American customer satisfaction index: nature, purpose, and findings. The Journal of Marketing, 7-18.

Giese, J.L., \& Cote, J.A. (2002). Defining consumer satisfaction. Academy of Marketing Science Review, 2000(1).

Gravetter, F. J., \& Forzano, L. B. (2012). Research Methods for the Behavioral Sciences $4^{\text {th }}$ ed.. Canada: Wadsworth Cengage Learning

Hersen, M. (Ed.) (2004). Comprehensive Handbook of Psychological
Assessment, Volume 2: Personality Assessment. Hoboken, NJ: John Wiley \& Sons Inc.

Hom, W. (2000). An overview of customer satisfaction models. Customer Satisfaction Models. (100-110).

Jokowi \& Jusuf Kalla. (2014). Jalan Perubahan Untuk Indonesia yang Berdaulat, Mandiri, dan Berkepribadian: Visi, Misi, dan Program Aksi. Diakses dari kpu.go.id/koleksigambar/VISI_MISI_ Jokowi-JK.pdf

Kaplan, R. \& Saccuzzo. D. (2009). Psychological Testing Principles, Applications, and Issues 7th ed. Belmont, CA: Wadsworth.

LAPOR. (2015). https://www.lapor.go.id/ pengaduan/1352998/evaluasi-kinerjastaf-kelurahan-pondok-kelapa. $\underline{\mathrm{html}}$

Masnurdiansyah. (2016). Ombudsman RI : Keluhan buruknya layanan Pemda paling tinggi. Diakses pada 16 September 2017 dari https://news.detik.com/berita-jawabarat/d-3330136/ombudsman-rikeluhan-buruknya-layan an-pemdapaling-tinggi

Mill, R. C. (2011). A comprehensive model of customer satisfaction in hospitality and tourism: Strategic implications for management. International Business \& Economics Research Journal (IBER), 1(6).

Millon, T. \& Bloom, C. (2008). The Million Inventories: A Practitioner's Guide to Personalized Clinical Assessment. London: The Guilford Press

Nunnally, J.C. \& Bernstein, I.H. (1994). Pyschometric Theory Third Edition. New York : McGraw-Hill.

Oliver, R.L. (2015). Satisfaction: A behavioral perspective on the consumer (2nd ed.). New York, NY: Routledge.

Ombudsman. (2015). Statistik laporan/pengaduan masyarakat. 
102 Jurnal Al-Qalb, Jilid 10, Nomor 2, Oktober 2019, hlm. 91-102

Diakses pada 16 September 2017 dari www.ombudsman.go.id/index.php/lap oran/laporan-

statistik.html?download $=252$ :laporanstat istik-tahun-2015

Pratama, A. F. (2017). Masyarakat Jadi Tak Antusias Urus KTP Elektronik Akibat Blangko Kosong. Diakses dari http://www.tribunnews.com/nasional/ 2017/08/24/masyarakat-jadi-takantusias-urus-ktp-elek tronik-akibatblanko-kosong?page $=2$

Putra, L. M. (2017). Ombudsman: Keluhan Masyarakat Terhadap Pelayanan Publik Semakin Meningkat. Diakses pada 16 September 2017 dari http://nasional.kompas.com/read/2017 /03/14/00574011/ombudsman.keluhan. masyarakat.terhadap.pelayanan.publik. semakin.meningkat

Rahadian, L. (2017). Aduan e-KTP Dominasi Laman Layanan Kemendagri. Diakses pada 16 September 2017 dari https://www.cnnindonesia.com/nasion al/20170913192940-20-41539/aduane-ktp-dominasi-laman-layanankemendagri/

Sureshchandar, G. S., Rajendran, C., \& Anantharaman, R. N. (2002). The relationship between service quality and customer satisfaction-a factor specific approach. Journal of services marketing, 16(4), 363-379.

Sutrisno, E.D. Jokowi 100 hari, Menagih janji, visi dan misi presiden Jokowi. Diakses pada 23 September 2017 pada https://news.detik.com/berita/2815981 /menagih-janji-visi-dan-misi-presidenjokowi.

Utomo, S. D. (2011). Penanganan Pengaduan Masyarakat Mengenai Pelayanan Publik. BISNIS \& BIROKRASI: Jurnal Ilmu Administrasi dan Organisasi, 15(3).

Van Ryzin, G. G. (2013). An experimental test of the expectancy-disconfirmation theory of citizen satisfaction. Journal of Policy Analysis and Management, 32(3), 597-614.

Wang, Y. S., Tang, T. I., \& Tang, J. T. E. (2001). An instrument for measuring customer satisfaction toward web sites that market digital products and services. Journal of Electronic Commerce Research, 2(3), 89-102.

Yarmen, M., Bakti, I.G.M.Y., \& Sumaedi, S. (2016). Model kepuasan pelanggan bagi instansi pelayanan publik: Integrasi Indeks Kepuasan Maysarakat (IKM) dengan National Customer Satisfaction Index (NCSI). 11th Annual Meeting on Testing and Quality 2016.

Yüksel, A., \& Yüksel, F. (2001). The expectancy-disconfirmation paradigm: A critique. Journal of Hospitality \& Tourism Research, 25(2), 107-131.

Yüksel, A., \& Yüksel, F. (2017). Consumer satisfaction theories: a critical review. Tourist Satisfaction and Complaining Behavior: Measurement and Management Issues in the Tourism and Hospitality Industry, 95-132.

Tempo.Co. (2016). Banyak eluhan Pungli, Depok Buka Layanan SMS Center. Diakses dari https://metro.tempo.co/ read/773608/banyak-keluhan-punglidepok-buka-layanan-sms-center

Weiten, W. (2007). Psychology: Themes \& Variations. Belmont, CA: Thomson Wadsworth 